This PDF is a selection from a published volume from the National Bureau of Economic Research

Volume Title: Structural Impediments to Growth in Japan

Volume Author/Editor: Magnus Blomström, Jennifer Corbett, Fumio Hayashi and Anil Kashyap, editors

Volume Publisher: University of Chicago Press

Volume ISBN: 0-226-06021-7

Volume URL: http://www.nber.org/books/blom03-1

Conference Date: Tokyo, Japan

Publication Date: January 2003

Title: Constraints on the Level and Efficient Use of Labor Author: Hiroshi Ono, Marcus Rebick

URL: http://www.nber.org/chapters/c9577 


\title{
Constraints on the Level and Efficient Use of Labor
}

\author{
Hiroshi Ono and Marcus E. Rebick
}

Japanese labor market institutions have been given substantial credit for Japan's enviable growth performance after World War II. The personnel management system - with its strong job protection, enterprise-based unionism, and intensive on-the-job training - is especially seen as a factor that allowed Japan to utilize imported technology so rapidly and successfully. High levels of training, along with group-oriented activities, have also been linked to the high quality of the Japanese goods that reached export markets in the 1970s and 1980s. Indeed, many Japanese workplace practices, such as quality-control circles, have been adopted to good effect in the United States and Europe. On the macroeconomic side, the coordinated but decentralized bargaining system is seen as providing for the wage flexibility that allowed Japan to adjust to supply shocks, such as the two oil crises, more rapidly than most other Organization for Economic Cooperation \& Development (OECD) economies. Finally, the egalitarian nature of the compensation system has been credited with providing the widespread prosperity that underlies domestic demand.

The prolonged slowdown of the 1990s has led many to question whether the institutions that were appropriate for the past are as wholesome for the health of the contemporary and future economy. In particular, the rise in

Hiroshi Ono is assistant professor at the European Institute of Japanese Studies, Stockholm School of Economics. Marcus E. Rebick is university lecturer and fellow of St. Antony's College and a member of the Nissan Institute of Japanese Studies, Oxford University.

The authors wish to thank Masayuki Kakuho and Hiromi Murata of Recruit Works Institute, Minoru Ito of the Japan Institute of Labor, Koichiro Masuda, Fumio Ohtake, Kazumi Ota, Yasuo Takahashi, and participants in the March 2002 National Bureau of Economic Research (NBER), Center for Economic Policy and Research (CEPR), and European Institute for Japanese Studies (EIJS) conference and the Oxford Labor Economics Seminar. All omissions and errors are of course our own. 
the unemployment rate since 1998 from around 3 percent to almost 6 percent has changed views about the macroeconomic role played by the labor market.

This disillusionment can be quickly summarized. Strong job protection makes it difficult for companies to effectively restructure their activities in response to the changing external environment. This means companies are less likely to improve their balance sheets. A poorly developed external labor market impedes movement of experienced and knowledgeable employees to companies where they might be more valuable. The government, lacking confidence in the external labor market's ability to absorb the unemployed, may have been reluctant to push for a more drastic resolution of the bad debt problem that hampers the financial system. Under conditions of weak demand, the coordinated bargaining system makes it difficult for employees to increase their incomes and thereby may reduce domestic demand. Wage restraint is contributing to the deflation that currently is making difficulties for the effective use of monetary policy to revive economic growth. The aging of the work force makes it difficult to maintain a system where rewards are delayed and provided through promotion.

In this chapter, we address impediments to growth of the labor supply that are affecting the economy. Broadly speaking these are barriers to interfirm mobility for career employees, especially older men, and the difficulty women face in developing meaningful careers after taking time off to raise children. The latter depresses the labor force participation of women, especially the middle aged who have high educational attainment. Both of these issues are closely tied to the Japanese personnel management system and the legal framework that supports it.

A third impediment to growth on the labor supply side is the reluctance to accept large numbers of immigrants into Japan. The outlook is that Japan will continue with its existing policies in the short- to medium-run, and we do not consider the issue. We also do not address the way in which the unemployment benefit system may induce individuals to remain unemployed or how retirement benefits may encourage earlier retirement. With respect to the unemployment rate and participation rate of those over sixty, Japan is doing as well, if not better, at using potential labor resources than other OECD countries. It should be noted that the institutional features of the economy that we view as impediments would be significantly less problematic if the economy was growing at the rates seen through the 1980 s. If growth could be restored to 1980 s' levels through a surge in consumer and investment demand, much of the estimated losses to labor input might well be eliminated. However, that is unlikely to happen.

In the next section we provide an outline of the state of Japanese labor in 2001 , focusing on the extent to which institutions long seen as characteristic of the Japanese labor market have stayed the same or have been changing. Next, labor law and its consequences are discussed. We then look at impediments to the mobility of career employees (primarily men) that may 
be affecting growth; reasons why female labor force participation may be lower than levels seen in the United States are then examined. A quantitative perspective of the barriers is presented, including their overall implications for economic growth, the role of government policy in removing barriers is taken up, and we outline some areas in need of further research.

\subsection{The Employment System}

Although Japanese labor markets and institutions have been affected by the slump in growth that began in the 1990s, many of the main features remain largely intact. Widely noted aspects of the "Japanese model," such as enterprise-based unionism, low interfirm mobility, low unemployment, compensation within gender groups that is highly determined by age and seniority, large gender gaps in pay and promotions, and widespread use of mandatory retirement systems, have not dissolved in the face of the slowdown, despite press reports.

Evidence that the system has seen only minor change includes the following seven points:

1. Unions remain enterprise based, although union density has fallen steadily from around 35 percent at the time of the first oil shock (1973) to 21 percent in 2000 .

2. Job tenure for full-time regular employees remains high (Chuma 1997) and may even be increasing for some age groups.

3. Interfirm mobility rates remain virtually unchanged (Rebick 2001), although the number of employees forced to move because of bankruptcies has risen since the Asian economic crisis of 1998.

4. The 5.4 percent unemployment rate in May 2002, although high by Japanese standards, remains lower than the OECD average of 6.9 percent (OECD standardized rates).

5. Although performance- and results-related pay are becoming more important components of compensation arrangements, there is still a close relationship between age (and, to a lesser extent, seniority) and pay. Japanese age-wage profiles are steep mainly because blue-collar workers, as well as white-collar workers, see large increases in pay with age and seniority. With the exception of the managerial class of employees, the variance of pay within age groups remains stable (Genda and Rebick 2000). All of this is testimony to the continuing presence of enterprise unions and the influence of large, unionized firms on wage-setting practices outside the organized sector.

6. The gender pay gap has narrowed for full-time employees (especially the young), but the gap in hourly pay between female part-time workers and male full-time employees remains large. Because some 40 percent of women work part-time, the overall gender gap remains large. Among eight OECD countries including Korea, only in Japan is gender-rather than 
occupation, age, or industry - the most important determinant of wages (Tachibanaki 1998).

7. Japan has relatively few women in senior management or director positions compared with the United States or United Kingdom.

In spite of these observations, the Japanese model is evolving. Furthermore, most of the changes appear to be permanent, rather than temporary accommodations to economic conditions or the need for restructuring.

1. The proportion of individuals who are part-time or contract workers is increasing. In particular the percentage of employees working part-time has been rising steadily since the 1960 s, reaching as high as 39 percent of women and 13 percent of men in 1999 (OECD 2001). The number of temporary agency workers remains low at about 1 percent of the work force, but has been increasing rapidly with liberalization of the laws regulating agency work.

2. There has been a decline in the family-based enterprise sector. Some women who would have been family workers and men who would have become self-employed after mandatory retirement are now in the part-time employee labor force. Although some of this trend may be due to small businesses suffering during the 1990s, much of it is due to other aspects of the fundamental restructuring of the economy that is taking place.

3. Managerial compensation is becoming much more sensitive to various measures of performance. This is shown not only by surveys across companies, but also by the fact that the variance of pay of middle-aged men with higher education degrees has been increasing since the mid-1980s (Genda and Rebick 2000).

4. Attitudes are changing, especially among young people. Although the rates of separation for young workers have not increased much, most young employees say that they expect to change jobs before mandatory retirement. Young workers are quitting jobs at an increasing rate despite the poor state of the economy. In 1999, 32 percent of university graduates and 47 percent of high school graduates quit their first jobs within three years, both rates increasing since 1996 (Ministry of Labor [MOL] 2000a).

5. There is an increasing level of part-time work among the young. Often referred to as "freeters," they may be finding it difficult to find desirable full-time jobs in the current economic climate (Genda 2001). On the other hand, because of greater affluence, they may feel less pressured into taking jobs they don't really want.

\subsection{Worker Protection}

The most obvious problem facing companies burdened with redundant workers is the difficulty in shedding workers. There is long-standing agreement between management and labor in Japan that allows management to 
move workers around in the company (or even to loan workers to other companies) in return for a guarantee of employment until mandatory retirement age (Gordon 1985, 1998). Since the late 1970s this has been altered somewhat: Employees might be sent to other companies prior to mandatory retirement provided that the guarantee of employment still holds. In most cases, the original company ensures there are no financial losses to those transferred, making supplemental payments to workers if necessary. Although this is seen as a commitment by management to labor, which might be upheld in order to maintain the reputation of the employer (and industrial peace), it is reinforced by Japanese case law. (The remainder of this section relies heavily on Chuma 1998.)

Japanese labor law does not, by statute, provide guarantees of continued employment to employees, except that employers must give thirty days notice of dismissals. The Japanese constitution, however, enshrines the individual's right to work (Article 27) and the right to a minimum standard of "wholesome and cultured living" (Article 25). On this basis, Japanese courts have interpreted the law to impose four main standards on employers wishing to dismiss workers. The employer must show that:

1. It is under severe duress, such as facing possible bankruptcy, and existing redundancies are unavoidable.

2. It has made efforts to avoid redundancies by taking measures such as cutting overtime, hiring freezes, transfers, seconding workers to other companies, or seeking voluntary retirements.

3. It has consulted with its labor unions and employees.

4. It has a rational procedure for selecting those to be dismissed.

This case law developed in the 1950s in reaction to the widespread dismissals that followed implementation of the disinflationary Dodge Line of 1949-50 and the numerous industrial disputes that followed. The courts were concerned about dismissals being used as a way of undermining labor union strength, and the four conditions were aimed primarily at establishing what constituted unfair labor practice under postwar labor laws. The courts also established that redress for violation of these principles is not only compensation paid to the fired worker, but also reinstatement with back pay. Again, this was to act as a deterrent to labor practices deemed unfair.

The rulings had an effect: In 1975, at the peak of post-oil shock dismissals, the proportion of separations that were "at the employer's will" stood at only 10 percent, compared to 21 percent in 1954, and through the late 1970s firms in general took every action to avoid dismissals (Chuma 1998). The case law was further strengthened through rulings in the late 1970 s, at a time when a number of court cases examined dismissals for the purpose of labor adjustment during the downturn of the mid-1970s. In the 1970s and afterward, protection of workers from dismissals was extended 
to temporary and fixed-contract workers who had been repeatedly rehired after their contract expired and even to workers in the first, probationary year of employment.

Until 1998, the Labor Standards Law limited fixed-term contracts to one year or less. This was intended to force employers to offer indefinite-period contracts to employees. After the 1998 revision, the law allows contracts of up to three years, but only in the case where the employee is either over sixty, in a specialized occupation, or under other restricted circumstances determined by the Ministry of Health, Labor, and Welfare (MHLW). Furthermore, such a contract is renewable for only one year (Yamakawa 1998). This is a considerable restriction and has been heavily criticized (Ohtake 2001, Yashiro 1999). Since 1999, there have been a number of court rulings that have relaxed and, in at least one case, even dispensed with the framework of the four conditions, but it is still too early to know what overall effect these rulings will have (Yamakawa and Araki 2001).

\subsubsection{Consequences}

One problem with the level of job protection provided by dismissal case law has been the reluctance of employers to hire employees that they are not sure they wish to keep indefinitely. There also are negative externalities (Yashiro 1999). We later deal with one of the more serious of these: the lack of a well-developed external labor market and the information problems that result.

Another effect of current law is that it encourages companies to seek government help in the form of subsidies, protection from competition, and protection from creditors. Although labor case law was not responsible for this action, it is part of a general approach that provides economic security through employers rather than directly from the state or private insurance provision (Noguchi 1995). This may come at the expense of growth in total factor productivity (TFP). For example, Hayashi and Prescott (2002) note that TFP growth was exceptionally low at 0.8 percent per annum during 1978 to 1983 , when the government took action to subsidize and otherwise support industries that were in need of restructuring and firms endeavored to avoid dismissals.

Although arguments can be made for worker protection from the viewpoint of economic efficiency, there is little rationale for imposing a penalty whereby workers must be reinstated with back pay. Chuma (1998) argues that it would be better to simply impose a cash penalty that employers should pay workers who have been dismissed in violation of the conditions. He also suggests that courts may not be in the best position to evaluate the financial concerns of the company and that if the "severe duress" condition is imposed too stringently it may compromise the survival of the firm over the long run.

If a firm can no longer produce competitively, its human capital may 
have lost value regardless of what the firm is paying the employee. The benefits of worker protection may be quickly outweighed by the costs when there is a widespread drop in the value of some kinds of firm-specific human capital.

\subsection{Barriers to Mobility Between Firms}

There are many barriers to mobility in the Japanese labor market. Table 8.1 gives us some indication of the problems from the point of view of employees, based on a survey by Recruit, an employment service, in which individuals who wanted to change jobs were asked why they found it difficult to do so. Of course, there also are corresponding issues on the employer side of the labor market. We analyze all of these beginning with information problems, skill mismatch, and lack of pension portability. Seniority pay and age-based discrimination are then taken up, followed by differentials in pay by firm size and egalitarian pay norms. Job protection, the result of both law and firms' employment practices, is analyzed as a cause of both excess workers within firms and skill mismatch.

\subsubsection{Information Problems}

A long-standing problem in the Japanese labor market concerns the lack of available employment information. Commonly, workers do not know exactly (in terms of quality or quantity) what skills they have, and employers are unclear about the skills they need. That is, there has been a symmetric lack of information, and this is almost certainly due to the poor development of the external labor market in an economy with overall low mobility. "Better information for job seekers" has been a recurrent slogan in a situation where job postings tend to be ambiguous and crucial information, such as job description and required skills, is lacking (Japan Institute of Labor [JIL] 1998).

Employment information can be categorized into extensive information, which consists of information available to all job-seekers, such as firm

Table 8.1

Reasons Changing Jobs is Difficult: The Worker View

\begin{tabular}{lc}
\hline Reason & $\begin{array}{c}\text { Percentage } \\
\text { Giving Reason }\end{array}$ \\
\hline I exceed the age limit of the job postings & 40.8 \\
My work experience is not transferable to the general society & 23.4 \\
Returns to seniority will be lost and I will suffer wage loss & 21.8 \\
I do not know how to look for jobs & 19.1 \\
I will lose personal contacts established through my work & 14.1 \\
I will suffer a loss in my pension & 13.5 \\
\hline
\end{tabular}

Source: Recruit Works Institute (2001b). 
size and wages, and intensive information, which is more likely to be of an inside nature, such as work norms and work atmosphere of the employer (Rees 1966). Access to intensive information is a benefit insofar as it improves the quality of the job match and subsequently leads to higher rewards and better job satisfaction (Granovetter 1974). Watanabe (1992) explains that workers are more likely to obtain intensive information through acquaintances or former employers. According to Recruit's (2001b) survey, 41 percent of job seekers gathered employment information through contacts with friends, family, and former employers, and 72 percent of those (30 percent of all those who found jobs) found jobs through this channel. ${ }^{1}$

A labor market that favors informal job-search methods disadvantages job seekers who are not endowed with network ties or otherwise must seek re-employment through formal means. Workers seeking employment by means of application through employment agencies experience considerable hardship. This includes longer duration of job search and a poor quality of match (JIL 1998). This is not a problem peculiar to Japan.

In a society where a market for job changers is only just evolving and one-fifth of workers surveyed said that they do not know how to look for jobs, it is not surprising that firms specializing in headhunting and reemployment services are growing rapidly. Human resource firms are focusing on the information mismatch between buyers and sellers of labor. Their services include helping employers grasp which skills are needed and helping job seekers identify what types of skills they have and the options available to them. The government is gradually deregulating the market for private employment services, including temporary employment agencies, through revision of the Dispatched Employees Law. All this may lead to improvement.

Access to privileged information from social networks may not be limited to employment information. The quantity and quality of social resources are determined not only by an individual's network of acquaintances, but also by virtue of belonging to a particular organization. Establishing important connections with business partners and gaining trust and reputation within the firm are important social resources that workers acquire through their jobs. However, in most cases, such resources are lost if a worker relocates to a different establishment. Social resources acquired through business can be a benefit that facilitates workers' upward mobility within firms, but it can also be an impediment to interfirm mobility as workers fear that they will lose the personal contacts established through work.

1. In Granovetter's 1974 study of male white-collar workers in Boston, 56 percent used contacts. 


\subsubsection{Skill Mismatch}

Skill mismatch is a problem related to information availability, and it is of increasing concern in Japan. A survey of OECD economies reports that the Beveridge curve (which graphs unemployment rates against vacancies) has been shifting outward in Japan since the 1970s (Nickell et al. 2001) and has clearly accelerated in the late 1990s (Genda and Rebick 2000). This implies more jobs are available for any given unemployment rate, and that suggests there may be an increasing mismatch of skills. A survey of businesses and job seekers found that the level of vacancies $(690,000)$ and applicants $(740,000)$ across sixty occupational categories were fairly close, but within categories the ratio of vacancies to applicants ranged from 9.95 to 0.05 (METI-Recruit 2001).

A lack of necessary qualifications of job applicants, especially in some of the more specialized occupations, such as information technology (IT)related work, also is highlighted in the METI-Recruit study. It is clear that information flows must be improved in several ways: Firms need to convey to training providers just what skills are needed, and that information must also reach those who seek training or need it as a result of being laid-off. Outplacement departments could do a better job in regard to the latter. Public funds for retraining are offered to both companies and individuals, and there are proposals to increase the level of funding.

\subsubsection{Lack of Pension Portability}

Closely related to the problem of seniority-based pay (taken up later) is the lack of portability of private, firm-based pensions. Japan implemented a policy equivalent to the U.S. 401(k) defined-contribution plan in October 2001. Prior to this, there were no tax advantages to saving outside of the defined-benefit plans offered by firms.

Firm-based pensions take a number of different forms and can make lump-sum payments or provide annuities after retirement, but they share the characteristic of offering benefits based on years of service and final base salary. A recipient with thirty-five years tenure typically gets two to four years of base pay (that is, not including semi-annual bonuses), with the higher rates going to the better-educated employees of large firms (MOL 2000b). Portability problems arise because payouts often are reduced more than proportionately if an employee leaves before mandatory retirement. At the same time, an individual with low tenure at mandatory retirement (due to switching firms) may suffer a more than proportional reduction in benefits. In other words, the likely losses in earnings from a move extend to losses in pensions.

Ichinose (2001) uses pension tables to compute the pension losses that would be experienced by individuals who leave a large firm (more than 
1,000 employees) and move to a smaller firm at lower pay, which is the most common pattern. The losses are computed assuming that an individual is paid the average for the firm size and according to tenure. Pension losses can amount to $¥ 10$ million to $¥ 20$ million from an average pension of $¥ 35$ million, depending on age at separation. The younger the age, the greater the loss. For this reason, firms, especially large firms, offer additional lump-sum payments to individuals who leave under early retirement plans. The additional payments - typically between $¥ 5$ million and $¥ 10$ million一 cover some, but not all of the losses in pension value. In comparison to the overall losses of up to $¥ 100$ million that may be realized by workers who lose their jobs at large firms at age forty, these are not large quantities but, as suggested by the responses in table 6.1, have some influence on behavior.

\subsection{Seniority and Pay Structure}

There are significant tenure effects on earnings from seniority in the Japanese workplace. The work of Koike (1988), Hashimoto and Raisian (1985), and Mincer and Higuchi (1988) drew attention to the importance of on-the-job training and the development of firm-specific human capital for Japanese men. Along with the case studies and direct surveys of Koike, the latter two papers highlighted the apparently large increase in earnings with tenure (seniority) in Japan compared to the United States.

Work by Ohtake (1998) and others using cross-sectional microdata has, however, modified this view substantially. First, Ohtake finds that the return to tenure was smaller than had earlier been reported, even in the past. Second, he shows that the returns to tenure fell between 1980 and 1992, while rising in the United States. The cross-sectional data suggest that the increase in earnings attributable to tenure is 1 percent to 2 percent per year in Japan, still somewhat higher than in the United States. This is mainly, but not entirely, due to the fact that seniority has a much larger effect on the earnings of Japanese blue-collar workers than their U.S. counterparts.

Although there may well be an explanation in terms of firm-specific human capital to support the high returns to tenure in Japan, there are other views of this pattern that suggest that it may be a compensation policy developed in the 1920s and strengthened in the immediate postwar period to motivate workers and to provide for basic needs. In this view, the returns to seniority can be reduced through managerial reform without having any adverse effect on productivity, if pay-for-performance systems are introduced. This seems to be what is taking place, albeit at a slow pace (Rebick 2001). If the returns to seniority were further reduced, this should naturally raise the rate of mobility and also lessen the motivation of the courts to maintain such high standards of legal protection. Some of the arguments used by the courts have made reference to the need for worker protection 
given the nature of the Japanese employment system, including the pay accorded to seniority (Chuma 1998).

The tenure effect is so important for Japan because the average tenure is higher in Japan than in most other OECD countries for all age categories, Italy being a notable exception. As a result, middle-aged Japanese employees stand to lose more by leaving their firm than their counterparts in most other countries. This is particularly important for the higher-paid employees of large Japanese firms who receive almost double the median tenure of those in smaller firms (Ohtake 1998, table 4.7). The losses in earnings experienced by workers who leave firms after many years have an effect on mobility because they will increase resistance to the employer by unions or workers who know they have the support of the legal system.

\subsubsection{Age-Based Discrimination}

A consequence of the long-term employment and seniority systems is that Japanese firms impose age limits when recruiting and hiring. Workers exceeding the age limit of the jobs posted continues to be the most common reason for workers not changing jobs (Recruit 2001a, JIL 2001a). For this reason, here we pay special attention to the overt age-based discrimination in Japan's labor market.

Over 90 percent of Japanese firms impose age restrictions, generally thirty-five to forty, on their job openings. There is little variation across industry, firm size, and city size (JIL 2001b). There are many reasons why firms impose age limits, but the primary concern is that older workers do not fit into the firm's current employment system (table 8.2). These reasons make sense in light of the previous discussion. Because of the prevailing

Table 8.2 Reasons Firms Give for Age Restrictions in Recruitment

\begin{tabular}{lc}
\hline Reason & $\begin{array}{c}\text { Percentage } \\
\text { Giving Reason }\end{array}$ \\
\hline Older workers lack physical endurance & 33.8 \\
Older workers require higher wages & 26.9 \\
Occupational skills do not match firm's expectations & 24.9 \\
Desire to maintain a young workforce & 23.8 \\
To restrict number of job applicants & 20.2 \\
Older workers do not mix well with younger workers & 14.9 \\
Older workers are hard to handle & 12.9 \\
Older workers do not adapt well to corporate culture & 9.9 \\
To avoid exceeding the age structure of previous hires & 8.8 \\
Older workers lack motivation & 6.7 \\
Relative ease of hiring young workers & 5.7 \\
No posts for older workers and cannot accommodate them & 4.8 \\
Because other firms impose age limits & 3.0 \\
\hline
\end{tabular}

Source: JIL (2001b). 
norm of long-term employment, there is still a stigma attached to older or mid-career job seekers and firms often view them as hard to handle or as unable to adapt well to the corporate culture. It is also likely that many individuals who have lost jobs in other companies are simply not as capable, so a potential employers' view that they do not adapt well applied in their former company. The hesitancy to hire mid-career workers is partly rooted in the notion of equity. Indeed, from table 8.2 we can infer that the reason for age restrictions is less because of the relative ease of hiring young workers and more because "older workers do not mix well with younger workers" to avoid exceeding the age structure of previous hires.

Under pressure for reform, guidelines to abolish age limits in recruiting and hiring were introduced in October 2001 as part of the revised Employment Measures Law. However, the guidelines specify ten cases of exception where limits are acceptable. One exception is phrased almost specifically to prevent disruptions in the seniority system: "Cases where recruiting or hiring is intended for workers under a certain age in situations where, in order to make wage payments regardless of age to new employees, companies will be required to revise present regulations determining wages mainly in accordance with age" (JIL 2001a).

As it stands, the guidelines are viewed mainly as a cosmetic gesture; it simply states that employers should make efforts to abolish age limits. Unlike some countries, the Japanese guidelines do not impose any penalty for violations. A cursory glance at job postings after the guidelines went into effect confirms that the vast majority continue to have age limits. (See, e.g., http://www.employment.yahoo.co.jp/.) It is thus questionable whether they will have any effective results in the foreseeable future. The example of other countries' experience suggests that the problem will not go away even if the law is imposed with greater force. The high levels of tenure held by Japanese workers, especially in large companies, mean that their losses of both earnings and specific capital are likely to present them with even greater problems than their counterparts elsewhere.

\subsection{Firm-Size Differentials and Egalitarian Pay Norms}

An important stylized fact about mobility in Japan is that employees tend to move to smaller firms. In 1997 there were 1,670,000 employees who switched firms, and, by definition, separations equaled accessions (MOL 1998, table 10). If we restrict attention to firms with more than 1,000 employees, there were 192,000 separations involving interfirm moves, but only 172,000 accessions. The main source of this mobility deficit for large firms is found in the fifty and over age group. One reason for this distorted mobility pattern may be found in the egalitarian pay norms (described in the next section) and the presence of firm-size pay differentials.

Smaller firms pay substantially lower wages than larger ones, even after 
differences in worker attributes are taken into account (Tachibanaki and Ohta 1994; Rebick 1992). The reasons small firms pay less are not completely understood. Whatever they are, it is unlikely that the underlying causes, many of which are rooted in Japan's industrial organization, will change over the short- or medium-term. As we explain in the next section, the lower average pay levels found in smaller firms make them more likely to hire older employees.

\subsubsection{Maintaining Fairness}

Baron (1988) emphasizes the role of peer groups and normative comparisons in shaping worker assessments of fairness and explains that worker perceptions of fairness concerning output and rewards are governed more by social comparison when there is greater homogeneity among workers. He explains that work force homogeneity "facilitates identification with peers and co-workers, and that such homogeneity (is noted to be) greater in Japanese than U.S. facilities" (Baron 1988, 516). Under a system where wages and promotion are determined primarily by age and seniority, careful measures are taken to ensure that workers are promoted in accordance with seniority and that deviations from the main career track are minimized. Promotion rates among Japanese establishments vary across time, firm-size, industry sector, and sectoral output growth (Ariga, Brunello, and Ohkusa 2000). However, comparisons between Japan and the United States have consistently shown that the variance in wages among Japanese organizations are smaller than their U.S. counterparts (see, e.g., Ohta 2000 and Shirahase 2002).

Bringing older workers into the work force disrupts the seniority structure and hence the wage structure, because the employment system presumes entry from below. This is a reason why the introduction of pay-forperformance systems that actually deliver high variance in outcomes has been so slow. The preference for egalitarian pay in the presence of pay systems that have a strong age consciousness means that firms often feel that it is necessary to pay mid-career hires as if they had similar seniority to those of the same age in the firm. For example, a survey of 13,000 establishments (MOL 2000c) indicates that in the majority of firms surveyed, new employees are in principle paid approximately the same as existing employees of the same age and occupation. Only 15 percent indicated that they would pay the new hires less than their age cohort, presumably because they lacked firm-specific experience. Since much of the value of older employees may be firm specific, they are much less valuable after changing firms. It is easier for smaller firms, with lower average pay levels to fit these employees into their pay structure in a way that does not violate the egalitarian norms of the firm. This is one of the reasons why we see a marked tendency for older employees to move to smaller firms. Exceptionally able or skilled employees may stay in the large firm sector or move up to larger 


\begin{tabular}{lcc}
\hline & Participation $^{\mathrm{a}}$ & Parttime $^{\mathrm{b}}$ \\
\hline Japan & 59.6 & 39.4 \\
Sweden & 76.4 & 21.4 \\
United States & 70.8 & 18.2 \\
United Kingdom & 68.9 & 40.8 \\
Germany & 63.2 & 33.9 \\
France & 61.7 & 24.3 \\
Italy & 46.2 & 23.4 \\
\hline
\end{tabular}

Source: OECD (2001).

apercentage of females ages 15-64 in the labor force.

'Part-time female workers as a percentage of all female workers. Part-time is defined as less than thirty hours per week, except Japan where it is less than thirty-five hours per week.

firms but, on average, employees tend to move down the firm-size hierarchy.

We wish to emphasize that the combination of seniority- and age-related pay, the preference for egalitarian pay for similar age groups, and the firmsize differential distort the pattern of interfirm mobility in Japan. In particular, this means that the kinds of jobs available to older men in Japan will be severely restricted, which in turn makes it more difficult for larger firms to dismiss their employees.

\subsection{Female Labor Force Participation}

This section provides an overview of women's involvement in the Japanese labor force. Following sections analyze the specific barriers that have made that involvement less than it might be: exclusion from firms' internal labor markets and various aspects of the pension and benefit systems. Initiatives to reconcile work and family life are also taken up.

Table 8.3 shows female labor force participation rates and the rates of part-time work for women in Japan and elsewhere in OECD countries. Although Japanese women do not have the lowest rate of overall participation, it is clear that they are far from having the highest. There is therefore room for Japan to increase its labor inputs from this source. Furthermore, Japanese women are more likely to work part-time (defined as less than thirty-five hours per week) than most of their counterparts elsewhere. There are a number of reasons why these situations exist.

Women are more likely to exit the labor force for child rearing or other family responsibilities and later return to the labor force. This exit and reentry results in the $\mathrm{M}$-curve pattern of labor force participation rates. The M-curve has flattened since the early 1990s but as figure 8.1 shows, the mass 


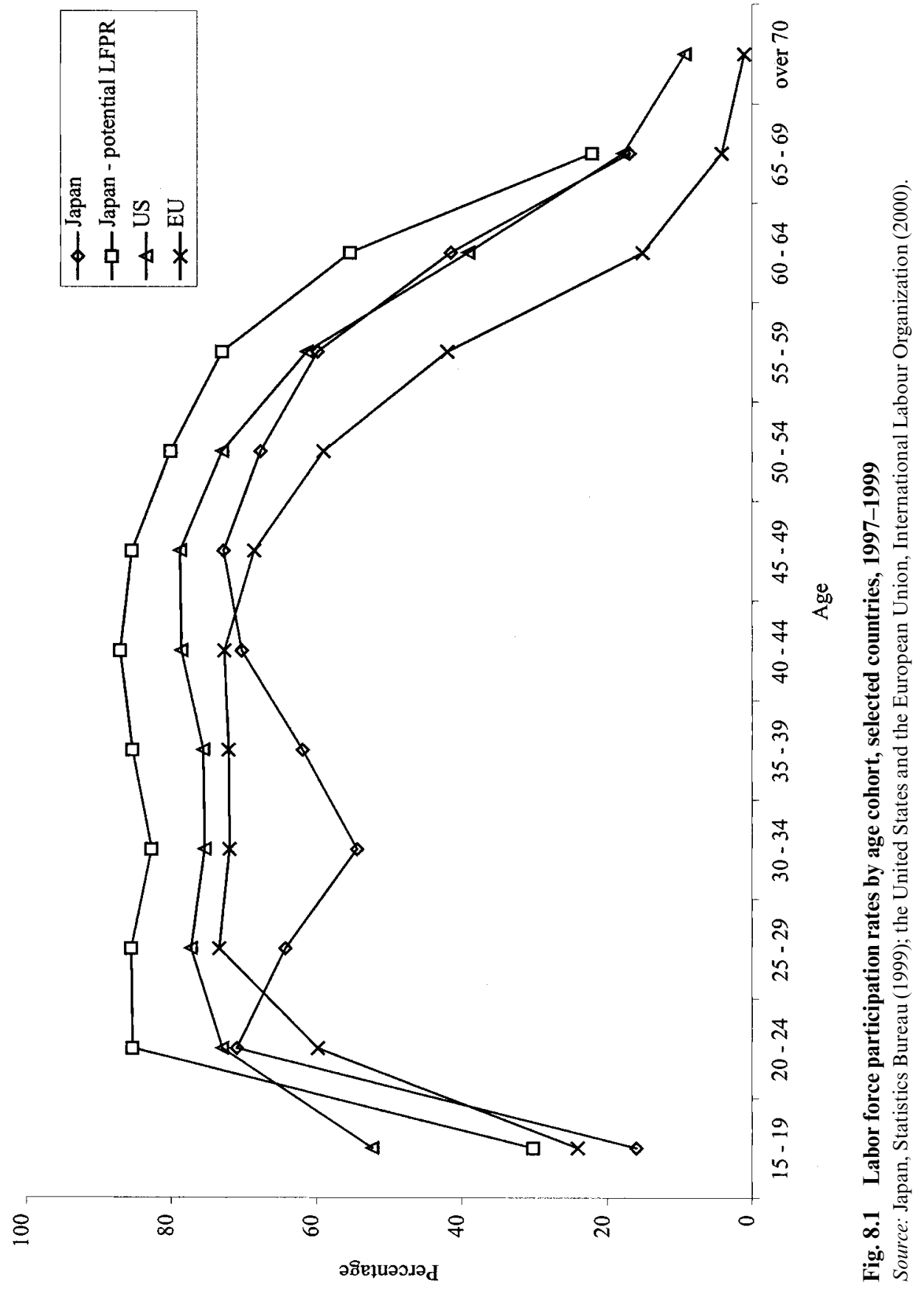


exit of women in their thirties continues to be a pronounced pattern in international comparisons.

However, the proportion of women who want to work but cannot also is highest among the thirties age group. When this proportion is included in the actual participation rates, we obtain a curve that resembles Western counterparts. This curve, known as the potential participation rate curve, has received considerable attention in policy circles concerned with Japanese women's requirements for reconciling work and family life. The potential participation rates provide an upper bound of the number of women who could be employed under conditions where various institutional barriers have been removed. For example, Osawa (1998), citing results from the 1992 National Survey on Lifestyle Preferences, reports that actual participation will resemble potential participation if the proportion of women who would work under conditions of reliable child care facilities are included.

Another feature concerns the growth in part-time employment. As figure 8.2 shows, the proportion of women in regular employment has changed little since 1965 . However, there has been a remarkable transition from the informal sector (self-employed and family workers) to part-time employment. This is attributable mainly to changes in industrial structure - a decline in agricultural employment and family-run work, a rise in work opportunities in firms (Nagase 1997), and a relative improvement of female wages (Shimada and Higuchi 1985).

Women's working patterns are better understood by first accounting for their nonmarket activities. Although expectations and attitudes concerning traditional gender division of labor are declining, Japanese women still face pressure to remain full-time mothers for children under school age and must maintain flexible work patterns to accommodate their nonmarket responsibilities. The Japanese government is attempting to change this situation through measures such as the New Angel Plan, which includes expansion of child care arrangements (MHLW 2001, 248-51).

Compounding these supply-side problems are demand-side impediments, such as the difficulty women face in being hired into the internal labor market and disincentives stemming from the unintended consequences in the tax and benefit system.

\subsection{Exclusion from Internal Labor Market}

Both men and women face problems if they change firms or leave the labor market for a time. Women are far more likely to temporarily leave the labor force. Japanese firms, especially the more desirable employers, typically create an internal labor market. This involves extensive training within the firm that presumes a long-term relationship between workers and employers. Employers thus seek workers who plan to remain with the 


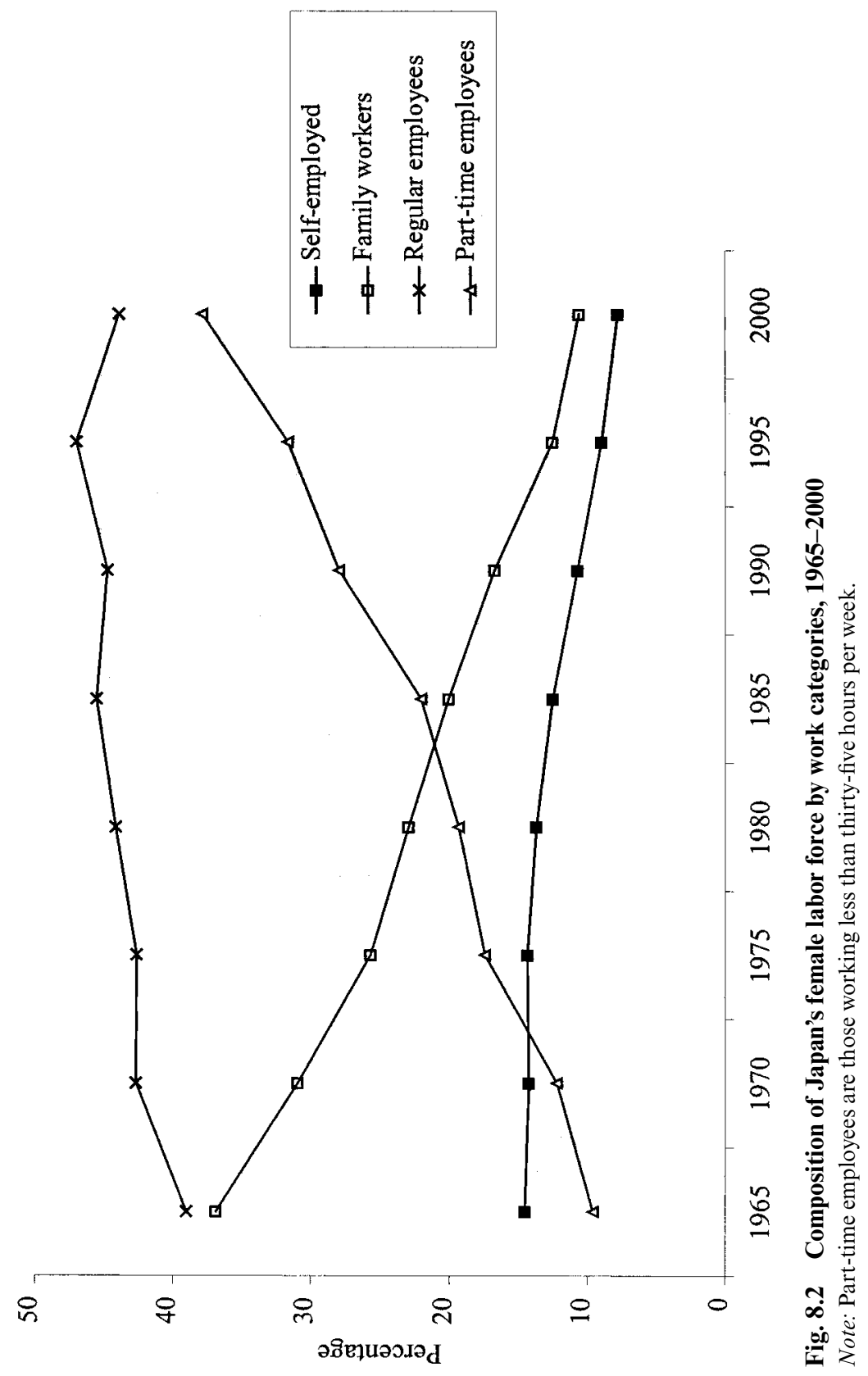


firm over a long period, so that the costs of their investments will not be lost. Because women are more likely to exit for reasons of marriage or child rearing, they face statistical discrimination (Brinton 1989). High-status positions in the seniority system are awarded to workers with longstanding tenure, so few women reach the upper echelons. Moreover, although Japanese women may enter large firms in equal proportions to men, only a very small proportion of the women even enter career-track positions. It is not that there has been a glass ceiling in Japan, it is that there has not even been a ladder.

The common route for women is to re-enter the labor force as part-time workers. Women who re-enter the market tend to find employment in smaller firms. In fact, Saso (1990) explains that older Japanese women are much more concentrated than young women in small firms and unskilled blue-collar occupations. Better educated married women with children are more likely to remain nonparticipants, other things being equal. This may be because the available jobs are not interesting or otherwise attractive to such women, who may prefer to develop nonmarket (leisure) activities.

Using census data for Japan and the United States, Brinton and Ngo (1993) estimate the index of gender segregation for the two countries in two occupational categories - managers/administrators and unskilled bluecollars. They find that segregation is greater in Japan among managers/administrators, and the segregation is greater among older age groups in Japan, while it remains stable across all age groups in the United States. Among unskilled blue-collar occupations, segregation is greater in the United States, and while it decreases with age in Japan, it increases with age in the United States.

These findings are consistent with the M-curve pattern of labor force participation among Japanese women. The likelihood of their placement into the internal labor market at the port of entry is lower than men's, but their attrition rate is even greater, as large numbers of women exit the labor force for family duties. When they re-enter, they do so into unskilled occupations. This pattern of labor mobility results in higher gender segregation among management occupations and lower gender segregation among unskilled occupations for older workers.

\subsection{Tax and Benefit Systems}

The structure of tax and benefit schemes distorts the labor supply behavior of married women in part-time employment. For example, the second earned income is treated in such a way that the after-tax income of some households may actually decline if the second income exceeds the limit (usually around $¥ 1$ million per year). (Tax exempt status and pension benefits for spouses are not gender specific in Japan but we refer only to women, as we are analyzing their impact on married women in general and secondary wage earners in particular.) 
In general, the schemes originally were introduced to protect married women from declines in household income when they moved from market work to household work. However, because they rest on the implicit assumption that married women should remain as full-time housewives, the unintended consequences of such "policies to protect full-time housewives" (Higuchi 1995) have come under severe scrutiny amidst increasingly diversifying patterns of women's employment. There is strong evidence that women in Japan adjust employment hours and annual income so as not to exceed the critical exemption levels (Horioka 1999).

As a good basis for discussion, table 8.4 presents 1990 and 2001 surveys that examine how employment patterns of married women in part-time positions are affected by taxes and benefits. An increasing number of respondents - 36 percent in 1990 and 49 percent in 2001 - adjusted their employment level in response to these policies. Moreover, 70 percent of the wives of salaried workers responded that they would increase their work hours if these policies were removed. (National Survey on Lifestyle Preferences, as cited in Nagase 2001). Clearly, the proportion of women who withhold labor as a consequence of such policies is not negligible.

The following discussion focuses on three factors - the tax exempt status of spouses, social security programs, and fringe benefits provided by employers - and examines how they may constitute disincentives to married women's employment. A noteworthy pattern observed across the three factors is that the adjustments in labor supply are more pronounced among educated women (Abe and Ohtake 1997; Higuchi 1995). There are three principal explanations for this. First, education is positively correlated with wages, so highly educated women reach the critical level of earnings

Table 8.4

Reasons Married Women in Part-Time Positions Gave for Adjusting Income

\begin{tabular}{lcc}
\hline Reason for adjusting annual income & $1990^{\mathrm{a}}$ & $2001^{\mathrm{b}}$ \\
\hline Any reason & 35.7 & 49.1 \\
To avoid paying income tax & 30.0 & 27.8 \\
To avoid exceeding tax exempt and special tax exempt & & \\
$\quad$ status for spouses & 23.5 & 32.6 \\
To receive fringe benefits from spouse's employer & 12.0 & 15.7 \\
So health insurance and pension covered by spouse & 11.5 & 30.5 \\
So spouse's employer will not find out that I am working & 0.8 & 1.4 \\
To avoid paying unemployment insurance & 2.0 & 7.5 \\
\hline
\end{tabular}

Note: Multiple answers were allowed

${ }^{a}$ General Survey on Part-time Workers Condition conducted by the MOL, as cited in Higuchi (1995).

${ }^{\mathrm{b}}$ Recruit Works Institute (2001a).

cThe General Survey also asked this question in two other forms: "I plan in advance so that my annual income will not exceed $¥ 1$ million” (which is the usual tax-exemption) was checked by 16.2 percent of respondents and "I adjust my work patterns throughout the year so that my annual income will not exceed $¥ 1$ million” by 13.8 percent. 
more quickly than less educated women. Second, highly educated women have better knowledge of the lower and upper bounds of various exemptions and respond more sensitively. Third, wives' education is positively correlated with husbands' education (hence higher husbands' earnings), so they may have less incentive to work. Whatever the reasons, such an incentive structure depresses the rate of return to education for women, and discourages the younger generation of women from pursuing higher education.

\subsubsection{Tax Code}

The income tax code in Japan has undergone several revisions in the postwar period. The 1950 revision introduced a system that placed the tax burden on individual income instead of household income. However, because the per capita disposable income of a household declines as the number of dependents increases, the system also introduced exemptions for part of spousal income. In the latest version, introduced in 1988, spouse's income was tax exempt up to $¥ 700,000$ annually, after which for each $¥ 50,000$ incremental increase in income, the exemption decreased $¥ 50,000$, so the exemption became zero at $¥ 1.4$ million. This was an improvement compared to its predecessor because it eliminates kinks or discontinuities in (after-tax) household budgets. Still, even with the revisions, the marginal tax rate for households is higher when the spouse’s income is between $¥ 1$ million and $¥ 1.35$ million, than when it is over $¥ 1.35$ million.

Using the General Survey on Part-Time Workers Conditions, Abe and Ohtake (1997) examine the labor force participation rates of married women in part-time positions as a function of their annual earnings and show that the distribution is concentrated around the $¥ 1$ million mark, with a significant drop in participation for earnings over that. Nagase (2001) shows similar results using monthly (not annual) income. Abe and Ohtake furthermore show that the distribution of work-hours becomes a bimodal distribution when adjusted for hourly wages, with spikes concentrated around the hours where the budget constraints are discontinuous. An increase in wages implies that workers reach the ceiling more quickly, so the consequence is that workers work less hours. In other words, there is no incentive for married women to increase their supply of labor under the current system.

There also is ample evidence that nonconvexities in the household budget distort the labor supply of women. Higuchi (1995) and Osawa (1993) present theoretical discussion of the impact of tax exemption schemes on women's labor supply before and after the revision of 1988 .

\subsubsection{Benefits and Pensions}

Features of the social security system have been criticized for causing distortions in the labor supply of women. Under the current system, con- 
tributions to health insurance and public pensions are exempt for spouses provided that employment hours do not exceed 75 percent of hours worked by regular full-time workers and annual income does not exceed $¥ 1.3$ million. (The physically challenged and workers over sixty can earn $¥ 1.8$ million.) In addition, contributions to unemployment insurance are not required of a spouse with an annual income less than $¥ 900,000$ who works less than twenty hours per week. Hatta and Kimura (1993) argue that the current pension system clearly favors households with full-time housewives, and that the removal of such "artificial barriers" to women's employment will encourage more women to seek full-time employment. The rise in regular employment will increase the base of pension payments and subsequently alleviate the current imbalance between payments and receipts in the pension system.

The labor supply of married women is furthermore constrained by the fringe benefits provided by their husband's companies. Abe and Ohtake (1997) suggest this is the most important barrier to married women earning more than $¥ 1$ million per year. Higuchi (1995) reports that over 80 percent of Japanese companies provide fringe benefits for employee dependents (such as special benefits for families and children) averaging $¥ 9,300$ per month in 1992, but 60 percent of the companies will terminate benefits if spousal income exceeds a certain level, usually around $¥ 1$ million. The value of the benefit may not be substantial sum, but it affects the employment of 12 percent to 16 percent of married women (table 8.4).

\subsection{Initiatives to Reconcile Work and Family Life}

Under the Child Care Leave and Family Care Leave Law, child care leave became mandatory for enterprises with more than thirty employees, and family care leave became mandatory for all enterprises. Employees receive 25 percent of their wages while on leave. Despite this, a mere 0.6 percent of male workers took child care leave following the birth of a child in 2002, and this ratio has remained unchanged since 1997 (MHLW as cited in "Dansei no ikkyuu susumanu shocho" [No advances in child care leave among men in the ministries], Nihon Keizai Shimbun [Tokyo], 18 November 2002). The vast majority who take leave are women. Some 70 percent of women quit instead of taking maternity leave, citing reasons such as "it was not the right climate at work" (from the 1996 National Survey on Family Planning, cited in Breslin 1997, 292).

Companies that have re-employment schemes in which former employees are hired back receive subsidies to facilitate re-employment of women. The system is beneficial to both workers and employers insofar as it allows recovery of previous investment in employer-specific skills (Imada 1998). However, the proportion of companies that have the system stood at just 21 percent in 1996. Moreover, the system is subject to numerous terms and 
conditions. For example, only 14 percent of these firms will re-employ their returnees as regular employees. In short, the current system does not offer particularly promising prospects for women who seek re-employment.

The presence of small children dramatically reduces Japanese women's labor supply (Hill 1989; Nagase 1997; Ogawa and Ermisch 1996), to a degree beyond that witnessed in Western societies. For example, Tsuya, Bumpass, and Choe (2000) show that the percentage of wives employed among households with preschool age children is 37 percent in Japan and 58 percent in the United States. Studies have shown that maternity leave policies and access to child care facilities increase women's job continuity (with the same employer) or re-entry into the labor force (Nakamura and Ueda 1999). In particular, Higuchi, Abe, and Waldfogel (1997) show that child care leave had a positive and significant effect on married-woman job continuity in Japan, the United States, and United Kingdom, but the marginal effect was found to be largest in Japan. Although the number of women who take advantage of child care leave may be small, the authors argue that their findings are encouraging. They conclude that what is required is not only for companies to install child care policies, but to ensure an environment that allows workers to take advantage of such policies.

In response to growing worker demands, some Japanese companies have introduced family-friendly policies or measures that help employees reconcile the claims of work and family life (Sato 2000). Flexible working schedules, subsidies for the costs of family care, and provision of child care facilities in the workplace are common forms of these policies. The policies are a private initiative, but the MHLW has set up a system of awards for family-friendly firms to encourage their spread. The need for such policies is a high-priority issue in light of the changing values among Japanese workers. Survey results show that the proportion of men and women who support the traditional gender division of labor is rapidly decreasing, while the proportion of men and women who desire a balance between family and work is increasing. (Consider, e.g., the 1999 Nippon Hōsō Kyōkai (NHK) survey cited in Sato 2000.)

However, the implementation of family-friendly policies in Japanese firms remains limited. A MOL survey in 1997 (as cited in Sato 2000) found that 51 percent of Japanese firms had no family-friendly policies apart from the legal requirements. The survey also found great variation over firm size and industry, with large firms not surprisingly doing the most. ${ }^{2}$

2. The Ministry of Labor survey used a point scheme to tabulate the total number of points out of 24 family-friendly schemes installed by the employer. Close to 100 percent of establishments greater than 500 employees had installed some form of family-friendly policy averaging 11.7 points versus 44 percent and 3 points respectively among establishments with less than 30 employees, and over 95 percent of firms in finance and insurance had installed family-friendly policies averaging 7.8 points versus 40 percent and 1.5 points respectively in the construction industry (from the 1996 Survey on Women Workers' Employment Management, Women's Bureau, the Ministry of Labour, as cited in Sato 2000). 
A common way for Japanese families to reconcile work and family life is to depend on extended family - that is, their children's grandparents (Morgan and Hirosima 1983). Empirical studies have found that coresidence with grandparents greatly increases the probability of women's entry into regular employment (Nagase 1997), and increases employment hours (Tsuya, Bumpass, and Choe 2000). However, it should be noted that the proportion of elderly in need of care is increasing, and the burden of care will likely fall on women (Ogawa and Ermisch 1996; Osawa 1990). Hence, reliance on grandparents to support women's work lives cannot be a long-term solution.

\subsection{Quantifying the Barriers}

Our approach to understanding the extent to which problems in the labor market are affecting economic growth is based on simple growth accounting and looks at the medium term. We look for unutilized (or underutilized) labor assets and assume that they can be moved into production evenly over a given period. This lets us know how much the potential growth of the labor input could be altered if the impediments to the supply of this labor were removed. The resulting figure can then be multiplied by labor's share of national output (roughly 70 percent in the Japanese case) to yield a potential increase in output to the economy. This contribution is a one-time increase but, for a fixed period, represents an increase in the potential growth rate. The calculation is necessarily crude and depends a lot on the assumptions behind the estimates of the amount of labor that is not being utilized. Still, this is a useful exercise to gain some idea of the scale of the losses experienced by the economy from labor market supply problems.

We divide losses into four categories. One is excess labor being carried by firms that are avoiding firing workers. We include in this category the extent to which employers are unable to dismiss workers whose productivity is low due to mismatch, although we do not treat them separately. The second is losses from factors that may be increasing the extent of mismatch in the economy and thereby raising the natural rate of unemployment. The third relates to women working part-time and the fourth to women not working at all.

\subsubsection{Excess Labor}

It is difficult to know the extent to which firms are carrying excess labor. The MHLW in its quarterly Rōdō Keizai Dōkō Chōsa (Survey of Labor Economy) reports the percentage of establishments surveyed that have surplus workers, as well as the percentage with labor shortages, for different industries and occupations. These are useful for understanding cyclical conditions and how they differentially affect different parts of the labor market, but they give no real sense of the size of the problem. 
Japanese firms carry some employees on their payrolls who are sent home for spells, often on a rotating basis, during downturns. There are government subsidies in some cases to encourage firms to do this rather than dismiss the workers (Dore 1986). These individuals are addressed in the Labor Force Survey under a special category (kyūgyosh $a$ ) that includes all workers who are not at work on the survey day, including for illness or absenteeism. Hashimoto (1993) notes that the number of kyügyōsha moves counter-cyclically and that adjustment in their number is generally less important than adjustment in hours and inventory as aspects of company reactions to the business cycle. The number of kyügyōsha rose some 20 percent from 1989 to 2000, nowhere near the doubling of the unemployed. The increase represents some 200,000 employees, equal to 0.3 percent of total employment. This is a reasonable lower bound for the number of surplus workers in Japanese firms.

An approach for setting an upper bound is to look at figures for TFP growth and argue that slower TFP growth is due to labor hoarding during downturns. The 1990s were undoubtedly a period of slower TFP growth, as was the mid-1970s following the first oil shock. Hayashi and Prescott (2002) calculate, after taking account of working hours, that TFP grew at 3.7 percent between 1983 and 1991 and then at only 0.5 percent between 1991 and 2000. They calculate that capital deepening increased during the 1990s from the 1980s, so it is unlikely that any drop in TFP growth could be attributed to a drop in the rate of investment. If all of the drop is attributed to excess labor being held in firms, we see a loss of 3.2 percent in the potential growth rate, assuming that this surplus labor could have been reemployed productively elsewhere. This is unlikely, as it would imply that almost a quarter of the labor force was surplus to firms' needs by the end of the decade.

Still, if we assume that if firms were able to dismiss workers more easily, the economy could reach the OECD average for TFP growth per annum during 1979-1997 of 1.1 percent, then surplus labor kept in firms lowers TFP growth by up to 0.6 percent per year. (In practice, the effect would be smaller because the reallocated labor would lose much of its job-specific human capital.) This implies that the quantity of surplus labor currently is around 5 percent of the employed, about the same as the number of unemployed. This number often is quoted in press accounts, although it is unclear where reporters get their figures. We take it as the upper bound for the number of redundant workers in Japanese firms.

\subsubsection{Skill Mismatch}

The problem of skill mismatch and the outward shift of the Beveridge curve was discussed earlier. The 2000 Labor White Paper uses time series of the unemployment rate and the vacancy rate to estimate that the natural rate of unemployment has risen from just over 2.0 percent to 3.5 
percent since 1993 (MOL 2000a). This is attributed mainly to structural change, particularly the decline in manufacturing, although aging of the work force is undoubtedly also part of the explanation. Using the result of the MOL, we attribute a loss of 1.5 percent in overall labor input to the mismatch problem in the labor market.

\subsubsection{Female Labor Supply}

We measure losses from barriers to the supply of women's labor as being losses from women working part-time and from women not participating in the labor force at all. We use the United States as a benchmark to estimate the extent to which labor market institutions reduce labor force participation. If Japan raised the participation rate of women from its level of 67 percent to the U.S. level of 77 percent, there would be an increase of about 15 percent in the female labor force input.

Japanese women put in around one hundred thirty-six hours per month, which is 82 percent of the one hundred sixty-five hours averaged by men. If employed Japanese women all worked as many hours as the men, they would increase their labor input by 21 percent. This is grossly unrealistic because some of these women are young and attending school; many would prefer to stay home with small children, even if child care is available; and many have household duties, including caring for elderly relatives, that take up much of their available time. However, it does serve as an upper bound for the effects of impediments that restrict hours of work. A plausible lower bound for the effect of disincentives to working full-time comes from Higuchi (1995). He estimates that married women who deliberately constrain their hours because of the tax and benefits system lower the overall labor input of women by 1.4 percent.

For our estimate of the contribution of impediments that encourage part-time work, we look at what would happen if the rate at which women twenty-five to sixty-four in Japan worked part-time was at the U.S. level (20 percent) rather than its actual 42 percent. (Women younger than twentyfive are excluded because many are still in school. Women over sixty-four are more likely to wish to work part-time regardless of impediments to working full-time.) Japanese women twenty-five to sixty-four work about half as many hours as their full-time counterparts. If 50 percent of them worked full-time, this would increase the female labor input by roughly 10 percent. ${ }^{3}$

Adding the two effects (and compounding), gives a total increase in the labor input of women of 26.5 percent. In terms of the overall labor force, this is an increase of around 11 percent. This figure is slightly smaller if ad-

3. Computed as the share of women working part-time multiplied by the share of hours of full-time women worked by part-time women multiplied by the share of women switching from part- to full-time work: $0.4 \cdot 0.5 \cdot 0.5=0.1$. 
justed for quality. (Experience is an important component of quality and, on average, female workers have less of it than male workers.)

\subsubsection{Overall Implications for Economic Growth}

Table 8.5 summarizes the calculations. The results are intended to give some idea of how much of an impediment to economic growth the factors mentioned might be. Output might be increased by between 9 percent and 12 percent. This is approximately equal to a 1 percent increase in the potential growth rate of the economy over a ten-year period. This is, of course, only a one-time benefit that the Japanese economy could exploit, but it is hardly a negligible one.

One question that naturally arises is why the impediments to the mobility of male employees that we examined have not been a problem in the past. In fact, many of the institutions, including the strong protection of regular employees and the personnel management system, have previously been analyzed by many observers as great strengths (Koike 1988). Our argument is that these institutions have been successful under the strong demand conditions that characterized the macroeconomy in Japan up to the 1990 s, but they have not been successful under stagnant demand thereafter.

Aging of the work force also means that Japanese personnel practices are in need of reform, but change has been slow so far (Ariga, Brunello, and Ohkusa 2000). Under these conditions, institutions which were well suited to a high-demand, moderate-to-rapid growth environment may become problematic. This is one area where better theoretical understanding of institutions under different growth environments is needed.

Table 8.5 Effect on Labor Input and Economic Output from Changes in the Labor Market (\%)

\begin{tabular}{lcc}
\hline Factor & Labor Input & Economic Output $^{\mathrm{a}}$ \\
\hline Reduce excess labor held by firms & $0.3-5.0$ & $0.2-3.5$ \\
Reduce skill mismatch & 1.5 & 1.1 \\
Increase women's hours $^{\mathrm{b}}$ & 4.1 & 2.9 \\
Increase women's participation $^{\mathrm{b}}$ & 6.2 & 4.3 \\
Total $^{\mathrm{c}}$ & $12.8-17.5$ & $9.0-12.2$ \\
\hline
\end{tabular}

Note: As explained in the text these are one-time effects that would be spread out over several years.

${ }^{a}$ Computed as the increase in labor input (stub column) times labor's share of output (70 percent).

${ }^{\mathrm{b}}$ Computed by multiplying the figures in the text by the proportion of women in the labor force (41 percent).

'The effect of the two contributions concerned with women are compounded in calculating the total. 


\subsection{Role of Government Policy}

Given that impediments to potential growth exist, how can government policy address them? We are unable to quantify the extent to which government actions may be able to address the issues raised here, but we can distinguish those areas where appropriate government policy should be able to increase effective labor inputs into the economy.

Table 8.6 provides a summary look at the role that government policy could play. Many of these policies are already being introduced or are under discussion in government deliberative councils. Looking at the mobility of male employees, it is clear that government legislation can change the nature of employment protection given employees. If the costs of dismissal can be reduced for employers, then this should release labor for more productive use. As suggested by Ohtake (2001), revision of the laws governing fixed-term employment should make it easier for employers to hire workers without making indefinite commitments to them. Both of these actions will undermine some of the loyalty of employees toward the firm, but this must be weighed against the demoralization felt by many employees who are not contributing much to the output of their firm.

There is probably not much that government policy can do to change the nature of personnel management in the Japanese firm, although it can continue to promote the development of defined-contribution pension schemes. In this area, government policy is moving in the right direction.

Barriers to midcareer hires are unlikely to be removed by government action. The prohibition of age limits in job advertisements is unlikely to have much effect on age discrimination, at least in the short run. Subsidies

Table 8.6

Government Policies to Reduce Labor Market Impediments to Growth

\begin{tabular}{ll} 
Labor market problem & \multicolumn{1}{c}{ Government Policy Measures } \\
\hline $\begin{array}{l}\text { Employment protection } \\
\text { Seniority pay structures and egalitarian pay } \\
\text { norms }\end{array}$ & $\begin{array}{l}\text { Legislation to reduce the cost of dismissals } \\
\text { No measures }\end{array}$ \\
$\begin{array}{l}\text { Pension portability } \\
\text { Information problems in the job market }\end{array}$ & $\begin{array}{l}\text { Encourage defined-contribution plans } \\
\text { Further deregulation of the employment } \\
\text { placement industry }\end{array}$ \\
Barriers to midcareer hires & $\begin{array}{l}\text { Lead by example in the public sector } \\
\text { Abolish the exemption for dependent spouses } \\
\text { age female labor supply }\end{array}$ \\
$\begin{array}{l}\text { Female career interruptions during childbearing } \\
\text { greater participation of women } \\
\text { years }\end{array}$ & $\begin{array}{l}\text { Encourage family-friendly workplaces with day } \\
\text { care provision and re-employment for women } \\
\text { who take short career breaks }\end{array}$ \\
\hline
\end{tabular}


to encourage midcareer employment have been tried in the past and are too blunt a tool: They may well be taken up by firms that plan to hire middleaged and older workers anyway. The development of new career paths that can be entered by middle-aged men and women is something that firms will need to develop though their own action. The government may be able to play a useful role, however, by leading through example in its own employment policies.

The government is working at improving information provision in the labor market, but continued deregulation of the employment placement industry should help to change the environment. The government can play a leading role in the development of a more open environment for information through example, by making its own activities more transparent.

Much is already being done by the government to promote familyfriendly policies at firms and to develop day care provisions so that women can remain at work. The government is contemplating major reform of the income tax system that will abolish many of the features that discourage women from participating or working longer hours ("Haigusha Kujowa Shukushō mata wa Haishi wo Fukuda Kanbō Chōkan" [General Secretary Fukuda Says That the Tax Exemption for Spouses Should Be Reduced or Abolished] Asahi Shimbun, 16 May 2002; available at http://www.asahi. com/politics/reform/security/K200205160307071.html.

\subsection{Conclusion}

This chapter has examined a number of personnel practices, laws, and regulations that lower the supply of labor in Japan. Broadly speaking, there are two kinds of impediments: those that restrict the movement of labor between firms and those that discourage women from participating to a greater extent. There has been a symmetric lack of information between employers and job seekers, and this is almost certainly due to the poor development of the external labor market in an economy with overall low mobility. It has been quite difficult for a worker over thirty to find attractive job opportunities. This is especially true for women re-entering the labor force. For married women, barriers also include disincentives in the tax system and the dearth of meaningful work, especially for women re-entering the labor force after rearing children. Despite changes, further modifications in the legal structure and practices of Japan's employment system are necessary to facilitate the diversifying patterns of employment and work attitudes of both men and women. Using other OECD countries and especially the United States as a benchmark, we estimate that removal of these barriers would increase the productive labor supply in Japan by 13 percent to 18 percent and thus could raise the potential growth rate of the Japanese economy by roughly 1 percent a year over a ten-year period. 
There are a number of empirical and theoretical areas where further work is needed. First, we need to know more about the real extent of surplus labor within firms. This requires more detailed surveys of individual firms than have been carried out. Second, regarding midcareer hires and their pay, research is needed beyond the qualitative studies done by the government, especially concerning actual pay levels. Longitudinal data on individuals are needed to see who manages to make a midcareer move successfully. Third, further research in the area of labor market problems and social norms would help us better understand why certain features, such as egalitarian pay norms and firm-size differentials, are more persistent than others.

A better theoretical understanding of the way in which institutions that function well during periods of normal or rapid growth may become liabilities when growth is stagnant is especially important. The role of the family and of state policy and their effect on female labor supply during periods of rapid social change needs to be better understood. This could be usefully looked at in an international comparative perspective, especially southern European countries where women also have had less of a role in the labor market in the past but are now increasing participation.

Although changes to overcome some of the barriers, such as the poor provision of information in the labor market, are being promoted by government and business leaders, many other changes require broader transformation of the Japanese economy. As Noguchi (1995) has pointed out, Japanese economic policy is still based to a large extent on the premise that much of the security and welfare of individuals in the economy will be provided through their employers. Japanese labor law (as developed through case law), industrial policy, and financial regulation have been based on this assumption.

Policy makers and regulators in areas other than labor will need to change their approach for the full benefits of any change in labor regulations to be realized. The large-scale restructuring that is required if Japan is to continue to shift away from manufacturing and reduce the size of its construction industry also requires a shift toward increasing provision of security through private or state-provided insurance. This in turn may have the effect of introducing a different set of inefficiencies, including an increased rate of unemployment and earlier retirement. Policies will need to be designed carefully if this kind of outcome is to be avoided.

\section{References}

Abe, Yukiko, and Fumio Ohtake. 1997. The effects of income tax and social security on the part-time labor supply in Japan. Review of Social Policy 6:45-64. 
Ariga, Kenn, Giorgio Brunello, and Yasushi Ohkusa. 2000. Internal labour markets in Japan. Cambridge: Cambridge University Press.

Baron, James N. 1988. The employment relation as a social relation. Journal of the Japanese and International Economies 2:492-525.

Breslin, M. 1997. Japanese women want more children than their total fertility rate suggests. Family Planning Perspectives 29:291-92.

Brinton, Mary C. 1989. Gender stratification in contemporary Japan. American Sociological Review 54:549-64.

Brinton, Mary C., and Hang-Yue Ngo. 1993. Age and sex in the occupational structure: A United States-Japan comparison. Sociological Forum 8:93-111.

Chuma, Hiroyuki. 1997. Keizai-kankyō no henka to chūkō nensō no chōkinzokuka (The changing economic environment and the lengthening of seniority). In Koyō kankō no henka to josei rōdō (Changing employment customs and women's labor), ed. Hiroyuki Chuma and Terukazu Suruga, 47-114. Tokyo: Tokyo Daigaku Shuppankai.

. 1998. Kaikoken ranyō hōri no keizaigaku (The economics of the legal principle of abuse of the right to dismissal). In Kaishahōno keizaigaku (The economics of company law), ed. Yoshio Miwa, Hideki Kanda, and Noriyuki Yanagawa, 425-51. Tokyo: Tokyo University Press.

Dekle, Robert. 2000. Demographic density, per-capita consumption, and the Japanese saving-investment balance. Oxford Review of Economic Policy 16 (2): 46-60.

Dore, Ronald. 1986. Flexible rigidities: Industrial policy and structural adjustment in the Japanese economy, 1970-1980. Stanford: Stanford University Press.

Genda, Yuji. 2001. Shigoto no naka no aimai no fuan: Yureru wakamono no genzai (Vague anxiety amidst work: the shaking world of youth today). Tokyo: Chūōkōron Shinsha.

Genda, Yuji, and Marcus Rebick. 2000. Japanese labour in the 1990s: Stagnation and stability. Oxford Review of Economic Policy 16 (2): 85-102.

Gordon, Andrew. 1985. The evolution of labor relations in Japan: Heavy industry, 1853-1955. Cambridge, Mass.: Harvard University Press.

- 1998. The wages of affluence: Labor and management in postwar Japan. Cambridge, Mass.: Harvard University Press.

Granovetter, Mark S. 1974. Getting a job: A study of contracts and careers. Cambridge, Mass.: Harvard University Press.

Hashimoto, Masanori. 1993. Aspects of labor market adjustments in Japan. Journal of Labor Economics 11 (1): 136-61.

Hashimoto, Masanori, and Raisian, John. 1985. Employment tenure and earnings profiles in Japan and the United States. American Economic Review 75 (September): $721-35$.

Hatta, Tatsuo, and Yoko Kimura. 1993. Kōteki nenkin wa sengyō shufu setai wo yūgū shiteiru (The Japanese public pension system favors households with fulltime housewives). Kikan Shakai Hoshô Kenkyû (Quarterly of Social Security Research) 29:210-21.

Hayashi, Fumio, and Prescott, Edward. 2002. The 1990s in Japan: A lost decade. Review of Economic Dynamics 5:206-35.

Higuchi, Yoshio. 1995. Sengyō-shufu hogo seisaku no keizai-teki kiketsu (The economic consequences of policies to protect full-time housewives). In Jakusha hogo seisaku no keizai bunseki (Economic analysis of policies to protect the weak), ed. Tatsuo Hatta and Naohiro Yashiro, 185-219. Tokyo. Nihon Keizai Shimbunsha.

Higuchi, Yoshio, Masahiro Abe, and Jane Waldfogel. 1997. Nichi-bei-ou ni okeru ikuji kyūgyō shussan kyūgyō seido to josei shugyō (Childcare and maternity 
leave policies and women's employment in Japan, the United States, and the United Kingdom). Jinkō Mondai Kenkyū (Journal of Population Problems) 53:49-66.

Hill, M. Anne. 1989. Female labor supply in Japan. Journal of Human Resources 24:143-61.

Horioka, Charles Yuji. 1999. Japan's public pension system: What's wrong with it and how to fix it. Japan and the World Economy 11:293-303.

Ichinose, Tomohiro. 2001. Tenshoku ni yoru shōgai chingin no genshō to sōki taishoku yūgū seido (Early retirement plans and the decline in lifetime income resulting from job changes). Rōsei Jihō 3484:27-34.

Imada, Sachiko. 1998. Re-employing Japanese women: Female labor and sustained support. Japan Labor Bulletin 37 (June). Available at http://www.jil.go.jp.

Institute of Labor Administration. 2001. Sōki taishoku yūgū to kibō taishoku seido (Early retirement and voluntary retirement programs). Rōsei Jiho 3484:226.

International Labour Organization. 2000. Year book of labour statistics. Geneva: International Labour Office.

Japan Institute of Labor (JIL). 1998. Chūkōnensha no tenshoku jittai to koyō shokugyō tenbō (Employment outlook and state of job-changes among middleage and older workers). Japan Institute of Labour Report 111. Tokyo: JIL.

- 2000. 2000 survey on employment management: Managing of retiring older workers. Japan Labor Bulletin 39 (Oct). Tokyo: JIL.

- 2001a. Guidelines to abolish age limits in the revised employment measures law. Japan Labor Bulletin 40 (November). Available at http://www.jil.go.jp. _. 2001b. "Shitsugyō kōzō no kenkyū" (Structure of unemployment). Japan Institute of Labour Report 142. Tokyo: JIL.

Koike, Kazuo. 1988. Understanding industrial relations in modern Japan. London: Macmillan Press.

Mincer, Jacob, and Higuchi, Yoshio. 1988. Wage structures and labor turnover in the United States and Japan. Journal of the Japanese and International Economies 2:97-133.

Ministry of Economics, Trade, and Industry (METI) and Recruit Works Research Center. 2001. Koyō no misumattchi no jittai bunseki (Empirical analysis of mismatch in employment). Tokyo: METI and Recruit Works Research Center. Available at http://www.meti.go.jp/kohosys/press/0001722.remove597167316452/ 0/010719koyou.pdf.

Ministry of Health, Labour and Welfare (MHLW). 2001. Kōsei rōdō hakusho (White paper on welfare and labor). Tokyo: Gyōsei.

Ministry of Labor (MOL). 1998. Süji de miru koyōno ugoki (Employment mobility survey). Tokyo: Ministry of Finance Publications.

. 2000a. Rōdō hakusho (White paper on labor) Tokyo: Japan Institute of Labor.

2000b. Taishokukin seido no genjō to kadai (The current situation and problems in the company pension system). Tokyo: Rōmu Gyōsei Kenkyusho.

. 2000c. Tenshokusha no jittai (heisei 10 nen chōsa) (The current situation of job-changers - 1998 survey) Tokyo: Ministry of Finance.

Morgan, S. Philip, and Kiyosi Hirosima. 1983. The persistence of extended family residence in Japan: Anachronism or alternative strategy? American Sociological Review 48:269-81.

Nagase, Nobuko. 1997. Wage differentials and labour supply of married women in Japan: Part-time and informal sector work opportunities. Japanese Economic Review 48:29-42. 
2001. Pāto no chingin ni 103 man en no kabe wa jūyoka (Is the upper limit of 1.03 million yen significant in determining a wage rate for part-timers?). Japanese Journal of Labour Studies 489:60-61.

Nakamura, Jiro, and Atsuko Ueda. 1999. On the determinants of career interruption by childbirth among married women in Japan. Journal of the Japanese and International Economies 13:73-89.

Nickell, Stephen J., Luca Nunziata, Wolfgang Ochel, and Glenda Quintini. 2001. The Beveridge curve, unemployment and wages in the OECD. In Knowledge, information and expectations in modern macroeconomics: Papers in honor of Edmund S. Phelps, ed. Phillipe Aghion, Roman Frydman, Joseph E. Stiglitz, and Michael Woodford. Princeton, N.J.: Princeton University Press.

Noguchi, Yukio. 1995. 1940 nen taisei: Saraba "senji keizai" (The 1940 system: Japan under the wartime economy). Tokyo: Tōyō Keizai Shinpōsha.

Ogawa, Naohiro, and John F. Ermisch. 1996. Family structure, home time demands, and the employment patterns of Japanese married women. Journal of Labor Economics 14:677-702.

Ohta, Kiyoshi. 2000. Kokusai hikaku kara mita Nihon no shotoku kakusa (Income distribution in Japan from an international perspective). Japanese Journal of Labour Studies 480:33-40.

Ohtake, Fumio. 1998. The United States. In Wage differentials: An international comparison, ed. Toshiaki Tachibanaki, 108-144. London: Macmillan.

_. 2001. Koyō mondai wo kangaeru (Employment-related problems in Japan). Osaka: Osaka University Press.

Organization for Economic Cooperation and Development (OECD). 2001. Employment outlook. Paris: OECD.

Osawa, Machiko. 1990. Women's response to economic changes. Japan Labor Bulletin 29:5-8.

-1993. Keizai henka to joshi rōdō (Economic change and women's labor). Tokyo: Nihon keizai hyōronsha.

. 1998. Atarashii kazoku no tame no keizaigaku (Economics for the new family). Tokyo: Chūō Kōron.

Rebick, Marcus. 1992. The persistence of firm-size earnings differentials and labor market segmentation in Japan. Journal of the Japanese and International Economies 7:132-56.

1993. The Japanese approach to finding jobs for older workers. In As the workforce ages: Costs, benefits, and policy challenges, ed. Olivia Mitchell, 103-24. Ithaca, N.Y.: ILR Press.

- 2001. Japanese labor markets: Can we expect significant change? In Japan's new economy: Continuity and change in the twenty-first century, ed. Magnus Blomström, Byron Gagnes and Sumner La Croix, 120-41. Oxford: Oxford University Press.

Recruit Works Institute. 2001a. Hi-tenkei koyō rōdōsha chōsa 2001-Shufu pāto taima (Nonstandard employment survey-Married women in part-time employment). Tokyo: Recruit.

- 2001b. Working persons chosa 2000-Shutoken (Working persons survey 2000 - The greater Tokyo area). Tokyo: Recruit.

Rees, Albert. 1966. Information networks in labor markets. American Economic Review 56:559-66.

Saso, Mary. 1990. Women in the Japanese workplace. London: H. Shipman.

Sato, Hiroki. 2000. The current situation of "family-friendly" policies in Japan. Japan Labor Bulletin 39 (February): 5-10.

Shimada, Haruo, and Yoshio Higuchi. 1985. An analysis of trends in female labor force participation in Japan. Journal of Labor Economics 3:S355-74. 
Shirahase, Sawako. 2002. Nihon no shotoku kakusa to kōreishasetai (A study of income inequality and households with the elderly in Japan: A cross-national comparison with industrial nations). Japanese Journal of Labour Studies 500:72-85.

Statistics Bureau, Ministry of Public Management, Home Affairs and Posts and Telecommunications. Various years. Labor Force Survey Annual Report. Tokyo: Japan Statistical Association.

Tachibanaki, Toshiaki. 1998. Introduction to Wage differentials: An international comparison, ed. Toshiaki Tachibanaki. London: Macmillan.

Tachibanaki, Toshiaki, and Ohta, Souchi. 1994. Wage differentials by industry and the size of firms, and the labour market in Japan. In Labour market and economic performance: Europe, Japan and the U.S., ed. Toshiaki Tachibanaki, 56-92. London: Macmillan.

Tsuya, Noriko O., Larry L. Bumpass, and Minja Kim Choe. 2000. Gender, employment, and housework in Japan, South Korea, and the United States. Review of Population and Social Policy no. 9:195-220.

Watanabe, Shin. 1992. Tenshoku hōhō (Job change methods). Soshiki Kagaku 25 (4): 72-84.

Yamakawa, Ryuichi. 1998. Overhaul after 50 years: The amendment of the labour standards law. Japan Labor Bulletin 37:11.

Yamakawa, Ryuichi, and Araki, Takashi. 2001. Rōdō hanrei kono 1 nen no sōten (Labor law precedents 1999-2000: The issues involved). Japanese Journal of Labour Studies 496:2-37.

Yashiro, Naohiro. 1999. Koyō kaikaku no jidai: Hatarakikata wa dō kawaru ka? (The age of employment reform: How will our ways of work change?). Tokyo: Chūkōshinsho. 
